\title{
PUTUSAN PEMIDANAAN MELEBIHI TUNTUTAN DALAM PERKARA KORUPSI POLITIK
}

Kajian Putusan Nomor 1885K/PID.SUS/2015

\section{SENTENCING OVER THE PROSECUTORS' DEMANDS IN POLITICAL CORRUPTION CASE}

\author{
An Analysis of Court Decision Number 1885K/PID.SUS/2015
}

\author{
Budi Suhariyanto \\ Pusat Penelitian dan Pengembangan Hukum dan Peradilan MA RI \\ Jl. Jend. Ahmad Yani Kav. 58 Cempaka Puth Timur Jakarta Pusat 10510 \\ Email: penelitihukumma@gmail.com
}

\begin{abstract}
Naskah diterima: 31 Januari 2018; revisi: 12 Maret 2019; disetujui: 2 Mei 2019
http://dx.doi.org/10.29123/jy.v12i1.303
\end{abstract}

\begin{abstract}
ABSTRAK
Memasuki masa pemilihan umum atau pemilihan kepala daerah selalu muncul opini tentang korupsi politik, baik sebelum dan sesudahnya. Persoalan korupsi politik ini secara definitif dalam hukum positif tak diatur secara eksplisit sehingga dipertanyakan keberadaannya. Akan tetapi secara praktik penegakan hukum, terdapat putusan pemidanaan yang mengidentifikasi korupsi politik dan memperberat hukuman terhadap pelakunya. Bahkan pemidanaannya melebihi daripada pidana yang dituntutkan oleh jaksa. Menarik untuk dipermasalahkan yaitu: bagaimanakah eksistensi korupsi politik dalam perundang-undangan Indonesia; bagaimanakah praktik pemidanaan terhadap pelaku korupsi politik; dan bagaimanakah filosofi putusan pemidanaan melebihi tuntutan dalam perkara korupsi politik. Untuk menjawab ketiga permasalahan tersebut digunakan metode penelitian hukum normatif dengan pendekatan perundang-undangan, pendekatan kasus, dan pendekatan konseptual. Hasil pembahasan mengemukakan bahwa eksistensi korupsi politik tidak diatur secara eksplisit dalam undang-undang, tetapi merupakan perluasan tafsir atas delik korupsi menyalahgunakan kewenangan
\end{abstract}

dan melawan hukum yang dielaborasi dengan kejahatan politik. Putusan Nomor 1885K/PID.SUS/2015 menjatuhkan pemidanaan melebihi tuntutan atas tindak pidana korupsi politik. Melalui pemberatan pidana tersebut, majelis hakim hendak menjelaskan kualifikasi korupsi politik sebagai delik korupsi yang spesifik karena berdampak luar biasa bagi kerusakan tatanan penyelenggaraan pemerintahan.

Kata kunci: pemidanaan, melebihi tuntutan, korupsi politik.

\section{ABSTRACT}

Entering the general or regional head elections period and afterward, opinions about political corruption often emerge. Definitively the existing political corruption problems are not set explicitly in the positive law which raises questions. But in applied law enforcement, there happens to be sentencing that identifies political corruption and aggravates the punishment for the offender. The thing is the sentence goes beyond the prosecutors' demands. It is interesting to question in what way the political corruption exists in Indonesian 
legislation, and just how applicable the sentencing against offenders of political corruption, as well as what philosophy lies in imposing sentence over the prosecutors' demands in cases of political corruption. Normative legal research method through the approach of legislation, cases, and concepts used to answer these three problems. The results of the analysis suggest that the political corruption has not been explicitly regulated in the law, but is an extended interpretation of a delict of corruption in abuse of power against the law elaborated

\section{PENDAHULUAN}

\section{A. Latar Belakang}

Masalah korupsi telah lama mewarnai berbagai aspek dalam kehidupan masyarakat dan telah menjadi suatu fenomena persoalan nasional yang amat sukar ditanggulangi (Suhendar, 2015: 1). Upaya untuk memberantas korupsi di Indonesia sebetulnya sudah sangat banyak dilakukan, tetapi kenyataannya bukan berkurang malahan korupsi seakan menyebar dengan merata sampai ke daerah, dan uang yang dikorup bisa dalam jumlah yang juga sangat fantastis. Pola korupsi mulai dari yang sederhana dan dengan modus yang canggih, dapat dilakukan baik dari kalangan eksekutif, legislatif, dan yudikatif, hingga membuat keadaan semakin sulit untuk memetakan dari mana dahulu untuk membersihkan korupsi (Ganarsih, 2016: 110). Bahkan pasca reformasi yang menciptakan pemilihan langsung dari kepala pemerintahan daerah, juga mulai dijalari dengan benih-benih korupsi yang masif di daerah-daerah.

Desain korupsi yang berkait antar oknum antar lembaga baik di tingkat pusat maupun daerah yang ingin mempertahankan kekuasaannya tersebut, juga seiring dengan kehendak para "konglomerat hitam" yang juga with political crime. The decision of the Supreme Court Number 1885K/PID.SUS/2015 dropped a sentence over the demands of the prosecution of political corruption. Through the escalation of a sentence, the panel of judges attempts to explain the qualification of political corruption as a specific delict of corruption considering a tremendous negative impact it could cause to the governance system.

Keywords: sentencing, over the prosecutor's demands, political corruption.

menyokong modal dan mengharap imbalan berupa tender proyek-proyek pemerintahan. "Simbiosis mutualisme" terbangun di satu pihak bertujuan mencapai dan mempertahankan kekuasaannya, dan di pihak lain mendorong dengan modal ekonominya berinvestasi untuk memenuhi hajat calon pejabat yang didukung dalam pesta demokratis.

Sudah bukan rahasia umum bahwa ongkos untuk berkompetisi dan mendapatkan kekuasaan melalui mekanisme politik electoral sangat besar, mulai dari mencari dukungan dan rekomendasi partai politik, hingga mensosialisasikan dirinya saat kampanye, serta waktu pencoblosan (biaya saksi di tiap tempat pemungutan suara). Komitmen untuk melunasi hutang dukungan "ekonomi" tersebut akan terus "menghantui" pejabat yang berhasil menduduki kekuasaan pemerintahan. Tak terelakkan tercipta perbuatan korupsi politik dalam perjalanan hubungan transaksional (politik dan ekonomi) yang penuh dengan konspirasi guna mengeruk keuntungan dengan cara merugikan keuangan negara.

Kajian korupsi politik yang terjadi di berbagai negara modern menunjukkan bahwa korupsi politik memiliki dampak lebih dahsyat dibandingkan dengan korupsi yang dilakukan 
oleh orang yang tidak memiliki posisi politik. Entitas korupsi politik melekat secara berpilin dan berkelindan dengan kekuasaan. Korupsi politik lebih berada dalam stadium untuk mempertahankan dan memperluas kekuasaan. Korupsi politik yang sistemik merupakan kejahatan yang luar biasa (extra ordinary crimes). Korupsi politik terjadi baik di negara kapitalis, komunis, maupun fasis. Pada negara yang mayoritas penduduknya beragama apapun tidak kebal dari korupsi politik (Alkostar, 2009: vi). Perbedaan corak korupsi politik di negara yang satu dengan yang lain adalah intensitas praktik korupsi yang terkait dengan variabel respon kekuasaan pemerintah dan gerakan sosial (Alkostar, 2009: 162).

Munculnya korupsi politik berbanding lurus dengan lemahnya atau tidak adanya kontrol terhadap praktik penyelenggaraan kekuasaan negara. Lemahnya kontrol ini dapat ditimbulkan karena kondisi sosial ekonomi dan pendidikan masyarakat yang tidak memadai. Selain itu juga dapat muncul karena praktik kekuasaan politik itu sendiri yang opresif dan menyimpang dari norma moral dan hukum yang adil. Keberadaan praktik kekuasaan yang korup ini melalui budaya politik selalu berupaya mendapatkan legitimasi sosial politik (Alkostar, 2009: 163).

Subjek pelaku dari korupsi politik adalah orang atau badan yang memiliki posisi politik yang melakukan perbuatan melawan hukum. Perbuatan tersebut menimbulkan akibat hukum, politik, ekonomi, hak asasi manusia, dan moral. Melalui perbuatan tersebut, pelaku bermaksud menguntungkan diri sendiri, orang lain atau badan dengan cara menyalahgunakan kewenangan, kesempatan, dan sarana yang ada padanya karena jabatan atau kedudukan politik (Alkostar, 2009: 17).
Secara definitif, korupsi politik tidak ditemukan dasar normatifnya secara eksplisit. Dalam realitas, keberadaannya dalam kehidupan bermasyarakat dan bernegara adalah sangat nyata. Bahkan dapat dikatakan bukanlah hal yang baru. Hanya saja secara hukum positif, rangkaian perilaku korupsi politik ini perlu ditafsirkan dalam penerapan hukum pemberantasan korupsi. Secara doktrin, sebenarnya sudah lebih dari dua dasawarsa telah menjadi kajian ilmiah, salah satunya adalah Artidjo Alkostar dalam disertasinya yang berjudul "Korelasi Korupsi Politik dengan Hukum dan Pemerintahan di Negara Modern (Telaah tentang Praktik Korupsi Politik dan Penanggulangannya)." Selain itu secara praktik peradilan dalam putusan pengadilan, keberadaan korupsi politik ini ada dan dijadikan sebagai perhatian khusus dalam hal mempertimbangakn berat-ringannya putusan pemidanaan. Bahkan di antara putusan-putusan yang menyebutkan secara eksplisit tentang korupsi politik itu, menjadikannya sebagai alasan memperberat pemidanaan terhadap terdakwa pelaku korupsi politik tersebut hingga melebihi tuntutan dari jaksa penuntut umum.

Memang untuk masalah putusan pemidanaan melebihi tuntutan adalah sesuatu yang umum terjadi di mana atas pertimbangan dan keyakinan hakim menjatuhkan vonis melebihi apa yang dimohonkan oleh jaksa penuntut umum, asalkan pidana yang dijatuhkan tersebut masih dalam koridor undang-undang. Artinya hakim dapat memutus lebih tinggi dari tuntutan jaksa penuntut umum, namun tidak boleh melebihi batasan maksimum ancaman pidana yang ditentukan oleh undang-undang. Selain itu juga tidak diperkenankan memberikan putusan pemidanaan yang jenis pidananya (strafsoort) tidak ada acuannya dalam KUHP. 
Hakim dapat leluasa dalam menentukan berat ringannya pidana (stafmaat) dari jenis pidana (sebagaimana diatur dalam undang-undang) yang akan dijatuhkan sesuai batasan minimum umum dan maksimum umum yang ada, dalam konteks ini bergantung dari keyakinan dan filosofi serta tujuan pemidanaan yang hendak diterapkan oleh hakim (Sudharmawatiningsih \& Suhariyanto, 2015: 67-68).

\section{Putusan Nomor 1885K/PID.SUS/2015} ini menarik dari sisi alasan hukum pemberatan pidana, didasarkan atas adanya perbuatan korupsi politik di mana secara normatif tidak diatur eksplisit. Pada putusan tersebut, majelis hakim memutuskan menjatuhkan pidana kepada RISR yang didakwa melakukan tindak pidana korupsi dan tindak pidana pencucian uang selama 12 tahun. Pemidanaan ini melebihi tuntutan yang diajukan oleh penuntut umum yaitu sepuluh tahun. Sebelumnya RISR dijatuhi pidana penjara selama enam tahun oleh Pengadilan Negeri Semarang melalui Putusan Nomor 81/Pid.SusTPK/2014/PN.Smg yang notabene dikuatkan oleh Pengadilan Tinggi Semarang melalui Putusan Nomor 11/Pid.Sus-TPK/2015/PT.SMG. Pemidanaan oleh putusan kasasi yang melebihi tuntutan penuntut umum ini didasarkan atas pertimbangan bahwa:

Terdakwa sebagai Bupati Karanganyar menggunakan bantuan dana subsidi perumahan tahun 2007-2008 dari Kementerian Negara Perumahan Rakyat untuk kepentingan di luar peruntukannya, yaitu untuk kepentingan Masyarakat Berpenghasilan Rendah (MBR). Perbuatan terdakwa tersebut bertentangan dengan Peraturan Menteri Negara Perumahan Rakyat Nomor 05/Permen/M/2007 pada Pasal 3 dan Pasal 4 yang menentukan bahwa bantuan pembiayaan perumahan swadaya diberikan kepada kelompok sasaran, sehingga perbuatan terdakwa merupakan perbuatan melawan hukum.
Terdakwa mempergunakan sebagian uang hasil korupsi tersebut, yaitu sebesar Rp2.446.606.000,- untuk kepentingan pribadi, yaitu dibagikan kepada pengurus partai politik pendukung terdakwa dalam rangka Pemilihan Kepala Daerah Kabupaten Karanganyar tahun 2008, sehingga perbuatan terdakwa merupakan korupsi politik.

Istilah korupsi politik digunakan oleh majelis hakim kasasi dalam mengidentifikasi perbuatan korupsi terdakwa RISR. Menurut majelis hakim kasasi, terdakwa sebagai bupati bukan saja tidak menjadi pengayom, pelindung, panutan bagi rakyatnya, tetapi justru telah mengorbankan kepentingan rakyatnya untuk ambisi politik dan kepentingan pribadinya. Akibat perbuatan terdakwa, rakyat Kabupaten Karanganyar kehilangan peluang untuk memperoleh/memperbaiki rumah, sehingga niat baik pemerintah melalui Program Gerakan Nasional Pembangunan Sejuta Rumah menjadi terganggu, yang justru dilakukan oleh seorang pejabat penyelenggara negara/bupati. Alasan pemberatan pemidanaan melebihi tuntutan penuntut umum dengan didasari oleh pertimbangan hukum berkaitan dengan kualifikasi tindak pidana korupsi yang dilakukan terdakwa RISR sebagai korupsi politik ini menarik untuk dikaji.

\section{B. Rumusan Masalah}

Berdasarkan uraian latar belakang di atas, maka dapat dirumuskan beberapa permasalahan yang relevan di antaranya:

1. Bagaimanakah eksistensi korupsi politik dalam perundang-undangan di Indonesia?

2. Bagaimanakah praktik pemidanaan terhadap pelaku korupsi politik? 
3. Bagaimanakah filosofi putusan pemidanaan melebihi tuntutan dalam perkara korupsi politik?

\section{Tujuan dan Kegunaan}

Tujuan dilakukannya penelitian ini adalah untuk mengkaji dan menganalisis eksistensi korupsi politik dalam perundang-undangan di Indonesia, praktik pemidanaan terhadap pelaku korupsi politik dan filosofi putusan pemidanaan melebihi tuntutan dalam perkara korupsi politik. Secara praktis, kegunaan penelitian ini adalah sebagai saran kepada penegak hukum dan hakim khususnya dalam memberikan putusan pemidanaan yang sesuai terhadap para pelaku tindak pidana korupsi politik hingga bisa menjerakan, dan di sisi lain menjadi peringatan bagi calon-calon pelaku di masa akan datang untuk membatalkan niatnya. Adapun secara teoritis adalah mendorong para akademisi untuk membuat kajian penajaman tentang konstruksi teoritis dari korupsi politik yang telah dikemukakan dalam pertimbangan hukum putusan Mahkamah Agung.

\section{Tinjauan Pustaka \\ 1. Pemidanaan}

Menurut Sudarto, pemidanaan sinonim dengan penghukuman. Penghukuman berasal dari kata hukum, sehingga dapat diartikan sebagai penetapan hukum atau merumuskan hukumnya (barenchsten) (Sani et al., 2015: 13). Penghukuman yang dimaksud berkaitan dengan penjatuhan pidana dan alasan-alasan pembenar (justification) dijatuhkannya pidana terhadap seseorang yang dengan putusan pengadilan yang telah berkekuatan hukum tetap dinyatakan secara sah dan meyakinkan terbukti melakukan tindak pidana (Failin, 2017: 17). Sistem pemidanaan menurut Arief mencakup keseluruhan ketentuan perundang-undangan yang mengatur tentang bagaimana hukum pidana ditegakkan atau dioperasionalkan secara konkret, sehingga seseorang itu dijatuhi sanksi (hukuman pidana), ini berarti semua aturan perundangundangan mengenai hukum pidana substantif, hukum pidana formal dan hukum pelaksanaan pidana dapat dilihat sebagai satu kesatuan sistem pemidanaan (Dirgantara et al. 2017: 122).

\section{Tuntutan}

Penuntutan adalah tindakan penuntut umum untuk melimpahkan perkara pidana ke pengadilan negeri yang berwenang dalam hal dan menurut cara yang diatur dalam undangundang dengan permintaan supaya diperiksa dan diputus oleh hakim di sidang pengadilan (Pasal 1 angka 7 KUHAP). Eksistensi surat tuntutan merupakan bagian penting dalam pelaksanaan penuntutan. Surat tuntutan dibuat secara tertulis dan dibacakan di persidangan (Pasal 182 ayat (1) huruf c KUHAP). Isi surat tuntutan itu tidak diatur dalam undang-undang tetapi biasanya memuat kesimpulan penuntut umum yang bersangkutan, apakah ketentuan yang didakwakan kepada terdakwa terbukti atau tidak, jika terbukti disebutkan besarnya hukuman yang dimintakan atau jika tidak terbukti dimintakan pembebasan terdakwa (Lisi, 2017: 50).

Jaksa penuntut umum memperhatikan peran dan keadaan terdakwa dalam tindak pidana dalam menentukan besar kecilnya tuntutan (Santoso \& Ma'ruf, 2017: 366). Selanjutnya, putusan hakim memperhatikan tuntutan penuntut umum (Pelafu, 2017: 86) tersebut dalam menghukum atau membebaskan terdakwa. 


\section{Korupsi Politik}

Tentang korupsi politik, Encyclopedia Americana menjelaskan: "political corruption concern the illegal pursuit or misuse of public office. Electoral corruption includes purchase of votes with money, promises of office or special favors, coercion, intimidation, and interference with freedom of election." Konsep ini menerangkan adanya pemisahan antara korupsi politik dan korupsi electoral. Di mana korupsi politik memberi perhatian kepada pencarian yang tidak sah atau menyalahgunakan jabatan pemerintahan, sedangkan korupsi electoral atau korupsi pemilihan umum meliputi pembelian suara pemilih dengan uang, menjanjikan jabatan atau kemudahan fasilitas, hadiah khusus, paksaan, intimidasi dan campur tangan pada pemilihan umum yang bebas. Kendatipun ada nuansa perbedaan antara korupsi politik dan korupsi pemilihan umum, namun ada dampak yang sama dari akibat yang ditimbulkannya yaitu dampak politis. Keadaan politik yang bermasalah inilah yang merupakan salah satu elemen dari korupsi politik (Alkostar, 2009: 16).

\section{METODE}

Untuk menjawab permasalahan penelitian digunakan metode penelitian hukum normatif yang merupakan prosedur penelitian ilmiah dalam menemukan kebenaran berdasarkan logika keilmuan hukum dari sisi normatifnya (Kriekhoff, 2015: 57). Pendekatan yang digunakan dalam penelitian ini adalah pendekatan perundangundangan (statute approach), pendekatan kasus (case approach), dan pendekatan konseptual (conseptual approach) (Marzuki, 2014: 133). Adapun data yang digunakan adalah data sekunder, yang terdiri atas bahan hukum primer berupa peraturan perundang-undangan dan putusan pengadilan, serta bahan hukum sekunder berupa literatur dan hasil penelitian. Data yang telah dikumpulkan kemudian dideskripsikan dan diinterpretasikan sesuai pokok permasalahan, selanjutnya disistematisasi, dieksplanasi, dan diberikan argumentasi. Metode analisis yang diterapkan untuk mendapatkan kesimpulan atas permasalahan yang dibahas adalah melalui analisis yuridis kualitatif.

\section{HASIL DAN PEMBAHASAN}

\section{A. Eksistensi Pengaturan Korupsi Politik dalam Perundang-Undangan Indonesia}

Tindak pidana korupsi merupakan tindak pidana kerah putih (white collar crime), tindak pidana yang berdampak luar biasa (extra ordinary crime), tindak pidana yang terorganisir (organized crime), serta tindak pidana dengan dimensi-dimensi yang senantiasa berkembang (new dimention of crime) (Kristian \& Gunawan, 2015: 284). Modus operandi tindak pidana korupsi senantiasa berkembang seiring dengan perkembangan zaman dan perkembangan masyarakat. Tindak pidana korupsi merupakan tindak pidana dengan dimensi-dimensi kejahatan yang senantiasa mengembangkan alat yang digunakannya sesuai dengan perkembangan ilmu pengetahuan dan kompleksitas struktur kemasyarakatan. Untuk menanggulangi hal ini, tentu hukum juga tidak dapat statis melainkan harus dinamis mengikuti perkembangan zaman, perkembangan masyarakat, dan perkembangan dunia internasional khususnya dalam rangka penanggulangan (mencegah dan memberantas) tindak pidana korupsi (Kristian \& Gunawan, 2015: 54).

Pada kongres PBB Ke-VII tentang Prevention of Crime and the Treatment of 
Offenders di Manila tahun 1985, telah dibicarakan suatu tema yang tidak klasik sifatnya, yaitu "Dimensi Baru Kejahatan dalam Konteks Pembangunan." Salah satu hasil pembicaraan tentang "dimensi baru" ini yang memperoleh sorotan adalah tentang terjadi dan meningkatnya "penyalahgunaan kekuasaan" (abuse of power) oleh pejabat publik. Penyalahgunaan kekuasaan dalam bidang ekonomi ini melibatkan pihakpihak "upper economic class" (seperti para konglomerat) maupun "upper power class" (seperti pejabat tinggi) yang melakukan konspirasi dan bertujuan untuk kepentingan kelompok tertentu (Adji, 2009: 88).

Secara teknis, intervensi politik yang mengarahkan pemenang kontrak agar jatuh ke kroninya merupakan bagian dari proses korupsi politik. Kontrak yang menyangkut kepentingan publik, menuntut adanya akuntabilitas publik dalam proses penentuan pemenang, sehingga perlu adanya transparansi, kejelasan kriteria. Jika terjadi selingkuh kepentingan yang tercakup dalam pengertian korupsi politik, maka perlu adanya pengontrolnya (Alkostar, 2009: 169).

Korupsi politik merupakan korupsi yang dilakukan oleh para penyelenggara level tinggi, misalnya anggota dewan, menteri, dan eselon di bawahnya termasuk kepala daerah. Korupsi politik ini biasanya melibatkan para pengusaha dengan aset atau uang yang dicuri dalam jumlah besar. Sementara arena pencurian aset atau uang, terjadi di ranah perencanaan dan penganggaran pembangunan, pengadaan barang dan jasa pemerintah, pemberian izin usaha, pemberian kuota perdagangan dan tentu pemberian hibah ke masyarakat. Semua aset atau uang yang diambil biasanya sebagian digunakan untuk pendanaan politik, seperti setoran ke partai atau uang perahu, biaya kampanye dalam pilkada dan pembelian suara jelang pemungutan suara saat pemilu (www.beritasatu.com).

Pada satu sisi perbuatan-perbuatan pelaku korupsi politik seringkali merugikan keuangan dan perekonomian masyarakat dan negara dalam skala yang sangat besar ini. Di sisi yang lain, penggunaan aturan-aturan KUHP yang telah terkodifikasi tak jarang masih belum dapat menyelesaikan permasalahan tersebut. Seringkali aturan-aturan dalam KUHP tidak dapat memenuhi rumusan delik yang dituduhkan terhadapnya, artinya perbuatan itu secara formal tidak melawan hukum, meskipun masyarakat dapat menilai tingkat ketercelaan atas perbuatan yang dilakukan olehnya amat tinggi (Adji, 2009: 89). Pada konstelasi bentuk-bentuk kejahatan dalam KUHP Indonesia, kejahatan korupsi politik berada dalam area pertimbunan (pertemuan) lingkaran kejahatan jabatan, korupsi (suap), dan kejahatan politik (Alkostar, 2008b: 36).

Arief mengategorikan kejahatan politik dalam dua kelompok, yaitu: Pertama, kejahatan oleh pemegang kekuasaan, yang biasanya dilakukan oleh pejabat, penguasa, politisi; dan kedua, kejahatan terhadap sistem kekuasaan, yang dilakukan oleh warga masyarakat. Kejahatan oleh pemegang kekuasaan sering disebut dengan berbagai istilah, antara lain: "kejahatan/tindak pidana jabatan", "crimes of the powerful", "abuses of public and political power", "crimes by government", "crimes of politicians in office", "top-hat crimes", "white collar crime" (Arief, 2008: 177). Adapun ciri-ciri (karakteristik) crimes of politicians in office ini menurut Dionysios Spinellis adalah:

1. Mengandung unsur penyalahgunaan jabatan publik (the abuse of political office);

2. Mengandung unsur pelanggaran 
kepercayaan (violation of trust) atau penyalahgunaan kepercayaan (abuse of confidence);

3. Berkaitan dengan kepentingan hukum masyarakat yang sangat serius;

4. Biasanya dilakukan dengan bantuan karyawan sipil atau karyawan partai sebagai kaki tangan, atau sebagai pelaku utama (sementara si politikus sebagai penganjur atau pelaku tidak langsung);

5. Sulitnya tindak pidana ini dideteksi dan dibuktikan;

6. Munculnya fenomena kembar berupa "penalisasi politik" (penalization of politics) dan "politisasi proses peradilan pidana" (the politicizing of the criminal proceedings) (Arief, 2008: 178-179).

Kategori kejahatan politik yang berkaitan dengan kejahatan oleh pemegang kekuasaan ini, beririsan dengan kejahatan jabatan. Adapun kejahatan jabatan dapat ditujukan kepada berbagai kepentingan hukum, baik kepentingan hukum merupakan kepentingan hukum dari masyarakat, maupun kepentingan hukum dari individu-individu. Suatu ciri yang bersifat umum dari kejahatan jabatan tampak pada kenyataan, bahwa semua kejahatan tesebut juga ditujukan kepada kepentingan hukum dari negara (Patiro, 2013: 82). Secara normatif, kejahatan jabatan terdapat pengaturannya dalam Pasal 413 sampai dengan Pasal 437 KUHP. Dalam KUHP tersebut tidak disebutkan secara definitif tentang kejahatan jabatan.

Pengaturan definitif kejahatan jabatan dapat ditemui dalam Pasal 106 Undang-Undang Dasar Sementara Tahun 1950 yang menyebutkan (Patiro, 2013: 98):

"Presiden, Wakil Presiden, MenteriMenteri, Ketua, Wakil Ketua dan anggota
Mahkamah Agung, Jaksa Agung, Ketua dan Wakil Ketua dan anggota Dewan Pengawas Keuangan, Presiden Bank Sirkulasi dan juga pegawai-pegawai anggota majelis tinggi dan pejabatpejabat lain yang ditunjuk dengan undangundang, diadili dengan tingkat pertama dan tertinggi juga oleh Mahkamah Agung, pun sesudah mereka berhenti berhubungan dengan kejahatan dan pelanggaran jabatan serta kejahatan dan pelanggaran lain yang ditentukan dengan undang-undang dan yang dilakukan dalam masa pekerjaannya kecuali ditetapkan lain dengan undangundang."

Berdasarkan uraian di atas, terdapat irisan kejahatan politik dengan kejahatan jabatan, tetapi di sisi lain terdapat pula irisannya dengan tindak pidana korupsi, sebab ketiganya merupakan bentuk penyimpangan yang dilakukan melalui struktur kekuasaan, baik pada tingkat negara maupun lembaga-lembaga struktural lainnya, tanpa atau dengan mendapatkan keuntungan materi baik bagi dirinya sendiri maupun orang lain merupakan penyalahgunaan kewenangan. Pendorong terjadinya korupsi adalah adanya kesempatan melalui jabatan atau kekuasaan, yang di dalamnya terkait kewenangan untuk melakukan sesuatu, untuk memperkaya diri sendiri, atau orang lain atau suatu korporasi yang dilakukan dengan menyalahgunakan jabatan atau kedudukannya (Iskandar et al., 2013: 107).

Korupsi politik dilakukan oleh pelaku dengan menyalahgunakan kewenangan, sarana, dan kesempatan yang melekat kepada kedudukan dan posisi sosial politik yang ada padanya. Penyalahgunaan posisi strategis pelaku korupsi politik berdampak pada bidang politik, ekonomi, hukum, dan pendidikan sosial yang negatif bagi rakyat (Alkostar, 2009: 163).

Memang KUHP tidak mengatur secara tegas tentang korupsi politik. Begitu pula 
Undang-Undang Tipikor yang ada sejak Orde Lama, Orde Baru, serta era Orde Reformasi tidak pernah mendefinisikan dengan tegas tentang korupsi politik, tetapi secara substansial korupsi politik selalu ada dan mengada dalam setiap pemerintahan negara. Kejahatan korupsi politik sering tidak dieksplisitkan dalam produk undangundang di negara modern karena pada dasarnya undang-undang adalah bagian dari proses dan produk lembaga politik baik parlemen maupun pemerintahan (Alkostar, 2008b: 36).

Sebagaimana unsur "melawan hukum" dari Pasal 2 Undang-Undang Tipikor memuat pengertian yang cukup luas, artinya selain sebagai pengganti unsur "melakukan kejahatan atau pelanggaran" yang identik dengan pengertian melawan hukum secara formal, maka unsur "melawan hukum" meliputi pengertian perbuatan melawan hukum dalam arti materiel, yang kemudian dikenal sebagai penerapan asas "materiele wederrechtelijk" dalam tindak pidana korupsi (Adji, 2009: 89). Pada perkembangannya penerapan asas ini dinyatakan inkonstitusional oleh Mahkamah Konstitusi pada Putusan Nomor 003/PUU-IV/2006 tanggal 25 Juli 2006. Artinya pengertian melawan hukum yang seharusnya dipergunakan di dalam pembuktian tindak pidana korupsi adalah hanya terbatas kepada pengertian melawan hukum formal (Suhariyanto, 2015: 424).

Secara definitif dalam Undang-Undang Tipikor tidak diatur secara formal istilah tindak pidana korupsi politik. Pada realitas penegakan hukum pemberantasan tindak pidana korupsi khususnya dalam praktik peradilan (putusan pengadilan), istilah korupsi politik mengemuka sebagai sebuah bentuk pemberatan atas setiap formulasi tindak pidana korupsi yang formal diatur dalam undang-undang. Perbedaan korupsi politik dengan korupsi jenis lain adalah pelaku yang memiliki posisi politik, sehingga jabatan atau kedudukan yang disalahgunakan adalah bermuatan politik. Lebih dari itu akibat yang ditimbulkan juga tidak hanya kerugian keuangan negara, tetapi juga akibat politik, ekonomi, moral, dan hak asasi manusia.

Korupsi politik mengandung unsur adanya eksploitasi politik dalam upaya memperoleh keuntungan politik (Alkostar, 2008b: 38). Artinya negara dirugikan secara sistematis akibat adanya kekuasaan politik yang curang dan mengeksploitasi harta kekayaan negara. Sejak dulu dalam sejarah evolusi dan revolusi kehidupan masyarakat manusia, kekuasaan selalu cenderung diperluas dan diperbesar oleh pemegangnya. Ketidakseimbangan antara proses membesarkan kekuasaan pemegangnya dan membesarnya kontrol, senantiasa menimbulkan korupsi kekuasaan (Alkostar, 2009: 165).

\section{B. Praktik Pemidanaan terhadap Pelaku Korupsi Politik}

Korupsi politik masih menjadi problem utama yang ditangani Komisi Pemberantasan Korupsi sepanjang 2017. Ini tampak dari meningkatnya jumlah kepala daerah dan anggota legislatif yang dijerat Komisi Pemberantasan Korupsi karena suap serta menyalahgunakan jabatan demi mempertahankan kekuasaan. Setidaknya 12 orang kepala daerah dari tingkat gubernur hingga bupati/wali kota dan wakilnya yang ditangani sepanjang tahun 2017. Jumlah ini naik dibandingkan dengan tahun sebelumnya, yaitu sepuluh orang kepala daerah yang ditangani Komisi Pemberantasan Korupsi. Untuk legislatif, ada 20 orang anggota Dewan Perwakilan Rakyat dan Dewan Perwakilan Rakyat Daerah yang 
ditangani, baik melalui operasi tangkap tangan maupun pengembangan perkara. Baik kepala daerah maupun anggota legislatif merupakan kepanjangan tangan dari partai politik (Kompas, 2017).

Diakui oleh penegak hukum bahwa ada tindak pidana korupsi yang melibatkan kepentingan politik baik dengan maksud dan tujuan maupun sarananya. Hanya saja oleh penegak hukum dalam hal pendakwaan tidak disebutkan istilah atau identifikasi korupsi politik, baru disebutkan dalam putusan pengadilan (khususnya pada tingkat Mahkamah Agung).

Sebagaimana dijelaskan sebelumnya bahwa secara definitif tidak diatur norma pelanggaran atas tindak pidana korupsi politik, tetapi dalam beberapa putusan pengadilan diidentifikasi istilah tersebut, yaitu dalam Putusan Nomor 1261K/Pid. Sus/2015 tanggal 8 Juni 2015 atas nama terdakwa AU; dan Putusan Nomor 1885K/PID.SUS/2015 tanggal 12 Oktober 2015 atas nama terdakwa RISR. Jika diperhatikan tanggal diputuskannya maka perkara atas nama AU diputuskan terlebih dahulu tentang adanya korupsi politik sebelum diputuskannya perkara RISR.

Perbedaan dari kedua putusan tersebut ada pada penerapan pasal yang dipidanakan oleh majelis hakim. Terhadap AU dikenakan Pasal 12 huruf a Undang-Undang Tipikor, dan terhadap RISR dikenakan Pasal 2 ayat (1) Undang-Undang Tipikor. Selain itu adanya perbedaan dalam hal putusan pemidanaannya, yaitu pada perkara AU penjatuhan pidana dendanya melebihi tuntutan jaksa penuntut umum, sedangkan pada perkara RISR penjatuhan pidana penjaranya melebihi tuntutan dari jaksa penuntut umum. Secara kasus posisi, kedua perkara tersebut dapat diuraikan sebagai berikut:
Pada perkara AU, dia didakwa dengan dakwaan kesatu primair melanggar Pasal 12 huruf a jo. Pasal 18 Undang-Undang Tipikor jo. Pasal 64 ayat (1) KUHP; dakwaan kesatu subsidair Pasal 11 jo. Pasal 18 Undang-Undang Tipikor jo. Pasal 64 ayat (1) KUHP; dan dakwaan kedua melanggar Pasal 3 Undang-Undang Nomor 8 Tahun 2010 tentang Pencegahan dan Pemberantasan Tindak Pidana Pencucian Uang jo. Pasal 65 ayat (1) KUHP; dan dakwaan ketiga Pasal 3 ayat (1) huruf c Undang-Undang Pencegahan dan Pemberantasan Tindak Pidana Pencucian Uang. Terhadap beberapa dakwaan tersebut maka jaksa penuntut umum mengajukan tuntutan yaitu:

a. Terdakwa terbukti bersalah melakukan tindak pidana korupsi sebagaimana dakwaan kesatu primair dan telah terbukti secara sah dan meyakinkan menurut hukum bersalah melakukan tindak pidana pencucian uang sebagaimana dakwaan kedua dan ketiga;

b. Menjatuhkan pidana terhadap terdakwa dengan pidana penjara selama 15 tahun dikurangi selama terdakwa ditahan dan pidana denda sebesar Rp500.000.000,- subsidair kurungan lima bulan;

c. Menghukum terdakwa membayar uang pengganti kerugian negara yang jumlahnya sebanyak-banyaknya sama dengan harta benda yang diperoleh dari tindak pidana korupsi in casu sebesar Rp94.180.050.000,dan USD 5,261,070;

d. Menjatuhkan hukuman tambahan kepada terdakwa berupa pencabutan hak untuk dipilih dalam jabatan politik;

e. Menjatuhkan pidana tambahan berupa pencabutan ijin usaha pertambangan atas nama PT AKJ seluas lebih kurang 5.000-10.000 ha yang berada di dua kecamatan yaitu Kec. Bengalo 
dan Kec. Kongbeng Kabupaten Kutai Timur berdasarkan Keputusan Bupati Kutai Timur Nomor 540.1/K.237/ HK/III/2010 tentang Persetujuan Izin Usaha Pertambangan Eksplorasi kepada PT AKJ tanggal 26 Maret 2010.

Pengadilan Negeri Jakarta Pusat melalui Putusan Nomor 55/PID.SUS/TPK/2014/PN.JKT. PST memutuskan dan menyatakan terdakwa AU tidak terbukti secara sah dah meyakinkan bersalah melakukan tindak pidana korupsi sebagaimana dakwaan kesatu primair, dan menyatakan bahwa terdakwa tidak terbukti secara sah dan meyakinkan bersalah melakukan tindak pidana pencucian uang sebagaimana dakwaan ketiga, sehingga membebaskan terdakwa tersebut dari dakwaan kesatu primair dan dakwaan ketiga.

Majelis hakim pengadilan tingkat pertama menyatakan terdakwa AU terbukti secara sah dan meyakinkan bersalah melakukan tindak pidana korupsi yang dilakukan secara berlanjut sebagaimana dakwaan kesatu subsidair dan menyatakan terdakwa tersebut terbukti secara sah dan meyakinkan bersalah melakukan tindak pidana pencucian uang yang dilakukan secara berulang kali sebagaimana dakwaaan kedua. Oleh karenanya terdakwa AU dijatuhi pidana penjara selama delapan tahun, ditambah dengan pidana denda sebanyak Rp300.000.000,- dengan ketentuan apabila denda tersebut tidak dibayar, diganti dengan pidana kurungan selama tiga bulan. Selain itu menghukum pula terdakwa AU untuk membayar uang pengganti kerugian kepada negara sebanyak Rp57.592.330.580,- dan USD 5.261.070.

Pada tingkat banding, Pengadilan Tinggi Jakarta melalui Putusan Nomor 74/PID/ TPK/2014/PT.DKI memutuskan dan menyatakan bahwa terdakwa AU tidak terbukti secara sah dah meyakinkan bersalah melakukan tindak pidana korupsi sebagaimana dakwaan kesatu primair dan menyatakan bahwa terdakwa AU tersebut tidak terbukti secara sah dan meyakinkan bersalah melakukan tindak pidana pencucian uang sebagaimana dakwaan ketiga sehingga membebaskan terdakwa AU tersebut dari dakwaan kesatu primair dan dakwaan ketiga.

Terdakwa AU terbukti secara sah dan meyakinkan bersalah melakukan tindak pidana korupsi yang dilakukan secara berlanjut sebagaimana dakwaan kesatu subsidair dan menyatakan terdakwa AU tersebut terbukti secara sah dan meyakinkan bersalah melakukan tindak pidana pencucian uang yang dilakukan secara berulang kali sebagaimana dakwaaan kedua. Oleh Pengadilan Tinggi Jakarta, terdakwa AU tersebut dijatuhi pidana penjara selama tujuh tahun, ditambah dengan pidana denda sebanyak Rp300.000.000,- dengan ketentuan apabila denda tersebut tidak dibayar diganti dengan pidana kurungan selama tiga bulan dan menghukum pula terdakwa AU tersebut untuk membayar uang pengganti kerugian kepada negara sebanyak Rp57.592.330.580,- dan USD 5.261.070.

Pada tingkat kasasi, Mahkamah Agung melalui Putusan Nomor 1261K/Pid.Sus/2015 membatalkan putusan pengadilan tinggi yang memperbaiki putusan pengadilan negeri, dan dengan mengadili sendiri menyatakan terdakwa telah terbukti secara sah dan meyakinkan bersalah melakukan tindak pidana "korupsi yang dilakukan secara berlanjut dan gabungan tindak pidana pencucian uang." Menjatuhkan pidana terhadap terdakwa dengan pidana penjara selama 14 tahun. Menjatuhkan pidana denda terhadap terdakwa sebesar Rp5.000.000.000,dengan ketentuan apabila pidana denda tersebut tidak dibayar diganti dengan pidana kurungan 
selama satu tahun empat bulan. Menghukum terdakwa untuk membayar uang pengganti sebesar Rp57.592.330.580,- dan USD 5.261.070. Menjatuhkan pula pidana tambahan terhadap terdakwa AU berupa pencabutan hak untuk dipilih dalam jabatan publik.

Majelishakim pada tingkat kasasimendasari alasan penjatuhan pidananya terhadap terdakwa AU atas dasar pertimbangan yaitu terdakwa AU telah melakukan suatu perbuatan dalam kategorisasi sebagai korupsi politik, yaitu dengan cara melakukan lobi-lobi proyek pemerintah yang dibiayai APBN secara aktif sehingga mendapatkan fee dari hasil usaha tersebut dan digunakan untuk kepentingan politik. Secara rinci majelis hakim kasasi menjelaskan bahwa:

1. Judex facti salah menerapkan hukum, karena tidak mempertimbangkan dengan benar hal-hal yang relevan secara yuridis, yaitu kedudukan terdakwa dalam hal ini selaku anggota Dewan Perwakilan Rakyat pada Komisi X dan selaku Ketua Fraksi Partai Demokrat, sehingga terdakwa merupakan penyelenggara negara;

2. Putusan judex facti bersifat kontradiktif, karena dalam pertimbangannya telah menyebutkan bahwa terdakwa melakukan lobi-lobi proyek pemerintah yang dibiayai dengan APBN adalah untuk kepentingan dirinya mencapai cita-citanya menjadi Ketua Umum Partai Demokrat dan calon Presiden. Hal tersebut secara yuridis memenuhi kualifikasi unsur hadiah dan janji yang patut diketahui dan patut diduga diberikan untuk menggerakkan agar melakukan dan tidak melakukan semata dalam jabatannya, seperti tertuang dalam unsur-unsur Pasal 12a Undang-Undang Nomor 31 Tahun 1999 sebagaimana telah diubah dengan Undang-Undang Nomor 20 Tahun 2001;

3. Terdakwa bersifat aktif meminta tolong saksi IM untuk menanyakan masalah tanah yang belum selesai suratnya. IM menempatkan terdakwa dan MN sebagai pimpinan fraksi, jadi perbuatan terdakwa merupakan condiko sene qua non (syarat mutlak yang harus ada) keluarnya SK Kepala BPN RI Nomor 11HP/BPN $\mathrm{RI} / 2010$;

4. $\quad$ PG adalah salah satu tempat bisnis terdakwa menerima fee di samping yang lainnya. Dalam PG, terdakwa sebagai pemilik yang dikelola oleh MRM dan Y serta MN sebagai bendahara. Uang tidak bisa keluar tanpa persetujuan terdakwa;

5. Perbuatan terdakwa mempunyai hubungan kausal dengan dititipkannya PT AK memperoleh proyek Hambalang dan persiapan terdakwa untuk menjadi Calon Ketua Umum Partai Demokrat;

6. Pembelian tanah di Yogyakarta mempunyai hubungan kausal dengan sisa uang dari fee-fee proyek yang berasal dari APBN sehingga terdakwa melakukan tindakan menyamarkan uang dari fee-fee proyek Hambalang/APBN;

7. Perbuatan terdakwa merupakan korupsi politik;

8. Rangkaian perbuatan terdakwa secara berlanjut memenuhi unsur-unsur Pasal 12a Undang-Undang Nomor 31 Tahun 1999 sebagaimana telah diubah dengan UndangUndang Nomor 20 Tahun 2001 jo. Pasal 64 KUHP sebagaimana dakwaan pertama dan Pasal 3 Undang-Undang Nomor 8 Tahun 2010 jo. Pasal 65 ayat (1) (dakwaan kedua) dan Pasal 3 ayat (1) Undang-Undang Nomor 15 Tahun 2002 sebagaimana telah diubah dengan Undang-Undang Nomor 25 Tahun 2003.

Berdasarkan pertimbangan hukum mejelis hakim di atas, jelas sekali bahwa rangkaian perbuatan korupsi politik terdakwa AU dalam konstruksi tindak pidana gratifikasi. Dia dikategorisasi sebagai penyelenggara negara yang menerima hadiah atau janji, padahal diketahui atau patut diduga bahwa hadiah atau janji tersebut diberikan untuk menggerakkan agar melakukan atau tidak melakukan sesuatu dalam jabatannya, yang bertentangan dengan 
kewajibannya. Tak hanya gratifikasi yang bersifat biasa, dalam arti bukan hanya untuk kepentingan memperkaya diri, tetapi dia mempunyai tendensi untuk mempergunakan dana yang dihasilkan dari upayanya melakukan lobi-lobi proyek pemerintahan tersebut untuk kepentingan politik.

Sehubungan dia bukanlah pejabat yang memiliki kewenangan langsung sehingga tidak dapat dijerat dengan tindak pidana korupsi penyalahgunaan kewenangan, tetapi keberadaannya beserta pengaruhnya telah berhasil menghubungkan dan memuluskan keluarnya beberapa kebijakan/keputusan dari pejabat yang berwenang. Dapat dikatakan bahwa tanpa peran serta atau turut campurnya, tidak akan mudah proyek tersebut memberikan keuntungan kepada korporasi (PG) yang notabene masih ada kaitannya dengan dirinya (persiapan suksesi sebagai ketua partai politik dan calon presiden).

Berbeda dengan pemidanaan korupsi politik AU yang didasarkan atas pelanggaran terhadap Pasal 12 huruf a Undang-Undang Tipikor, perkara korupsi politik dengan terdakwa RISR didasarkan atas pelanggaran Pasal 2 ayat (1) Undang-Undang Tipikor. Secara kronologis, RISR didakwa oleh jaksa penuntut umum secara berlapis dengan dakwaan kesatu primair melanggar Pasal 2 ayat (1) jo. Pasal 18 UndangUndang Tipikor jo. Pasal 55 ayat (1) ke-1 KUHP; subsidair melanggar Pasal 3 jo. Pasal 18 UndangUndang Tipikor jo. Pasal 55 ayat (1) ke-1 KUHP; lebih subsidair melanggar Pasal 5 ayat (2) Undang-Undang Tipikor jo. Pasal 65 ayat (1) KUHP; lebih-lebih subsidair melanggar Pasal 11 Undang-Undang Tipikor jo. Pasal 65 ayat (1) KUHP; dan dakwaan kedua, melanggar Pasal 3 Undang-Undang Pencegahan dan Pemberantasan Tindak Pidana Pencucian Uang jo. Pasal 65 ayat (1) KUHP. Adapun tuntutan penuntut umum pada Kejaksaan Negeri Karanganyar adalah agar:

1. Terdakwa dinyatakan telah terbukti secara sah dan meyakinkan menurut hukum bersalah melakukan tindak pidana korupsi sebagaimana diatur dalam dakwaan kesatu primair dan telah terbukti secara sah dan meyakinkan menurut hukum bersalah melakukan tindak pidana pencucian uang sebagaimana dakwaan kedua;

2. Menjatuhkan pidana terhadap terdakwa RISR karenanya berupa pidana penjara selama sepuluh tahun dikurangi selama terdakwa berada dalam tahanan dengan perintah agar terdakwa tetap ditahan;

3. Menjatuhkan pidana denda terhadap terdakwa sebesar Rp1.000.000.000,subsidair selama enam bulan kurungan; dan

4. Membayar uang pengganti sebesar Rp11.875.843.600,- dengan ketentuan akan diperhitungkan dan dikurangi dengan uang yang berasal dari hasil lelang terhadap harta benda milik terdakwa yang telah disita digunakan untuk pembayaran uang pengganti dan dalam hal terdakwa tidak mempunyai harta benda yang mencukupi untuk membayar uang pengganti tersebut, maka dipidana dengan pidana penjara selama enam tahun; serta

5. Menjatuhkan hukuman tambahan kepada terdakwa berupa pencabutan hak untuk memilih dan dipilih dalam pemilihan yang diadakan berdasarkan aturan-aturan umum.

Putusan Pengadilan Tindak Pidana Korupsi pada Pengadilan Negeri Semarang Nomor 81/ Pid.Sus-TPK/2014/PN.Smg tanggal 17 Februari 2015 yang amarnya menyatakan terdakwa RISR tidak terbukti secara sah dan meyakinkan bersalah melakukan tindak pidana dalam dakwaan kesatu primair, sehingga membebaskan oleh karenanya terdakwa a quo dari dakwaan kesatu primair tersebut.

Pengadilan Negeri Semarang menyatakan terdakwaRISR terbuktisecarasah danmeyakinkan 
bersalah melakukan tindak pidana "korupsi secara bersama-sama" dan "pencucian uang" karenanya memidana terdakwa RISR tersebut dengan pidana penjara selama enam tahun dan pidana denda sebesar Rp500.000.000,-, apabila tidak dibayar diganti dengan pidana kurungan selama tiga bulan. Selain itu menghukum pula terdakwa RISR untuk membayar uang pengganti sebesar Rp7.873.491.200,- dengan ketentuan jika terdakwa tidak membayar uang pengganti dalam waktu satu bulan setelah putusan yang berkekuatan hukum tetap, maka harta bendanya dapat disita oleh jaksa dan dilelang untuk menutupi uang pengganti tersebut, dan apabila harta bendanya tidak mencukupi untuk membayar uang pengganti, maka terdakwa dipidana dengan pidana penjara selama tiga tahun.

Pada tingkat banding, Pengadilan Tinggi Semarang melalui Putusan Nomor 11/Pid. Sus-TPK/2015/PT.SMG tanggal 29 April 2015 memutuskan menguatkan Putusan Nomor 81/ Pid.Sus-TPK/2014/PN.Smg, yang dimintakan banding tersebut. Pada tingkat kasasi, Mahkamah Agung melalui Putusan Nomor 1885K/PID. SUS/2015 membatalkan Putusan Nomor 11/ Pid.Sus-TPK/2015/PT.SMG yang menguatkan Putusan Nomor 81/Pid.Sus-TPK/2014/PN Smg, dan mengadili sendiri dengan menyatakan terdakwa RISR telah terbukti secara sah dan meyakinkan bersalah melakukan tindak pidana "korupsi secara bersama-sama" dan tindak pidana "pencucian uang."

Majelis hakim Putusan Nomor 1885K/PID. SUS/2015 menjatuhkan pidana kepada terdakwa pidana penjara selama 12 tahun dan pidana denda sebesar Rp1.000.000.000,- dengan ketentuan apabila denda tersebut tidak dibayar maka diganti dengan pidana kurungan selama enam bulan dan menghukum pula terdakwa untuk membayar uang pengganti sebesar Rp11.875.843.600,-. Jika terpidana tidak membayar uang pengganti paling lama dalam waktu satu bulan sesudah putusan pengadilan yang telah memperoleh kekuatan hukum tetap, maka harta bendanya dapat disita oleh jaksa dan dilelang untuk menutupi uang pengganti tersebut, dan jika terpidana tidak mempunyai harta benda yang mencukupi untuk membayar uang pengganti tersebut maka dipidana dengan pidana penjara selama tiga tahun, serta mencabut hak terdakwa untuk dipilih dalam jabatan publik.

Majelis hakim pada tingkat kasasi (majelis hakim yang sama dengan perkara kasasi terdakwa AU) mendasari alasan penjatuhan pidananya terhadap terdakwa RISR atas dasar pertimbangan, yaitu terdakwa AU telah melakukan suatu perbuatan dalam kategorisasi sebagai korupsi politik, karena terdakwa sebagai Bupati Karanganyar menggunakan bantuan dana subsidi perumahan tahun 2007-2008 dari Kementerian Negara Perumahan Rakyat untuk kepentingan di luar peruntukannya, yaitu untuk kepentingan masyarakat berpenghasilan rendah.

Perbuatan terdakwa tersebut bertentangan dengan Peraturan Menteri Negara Perumahan Rakyat Nomor 05/Permen/M/2007 pada Pasal 3 dan Pasal 4 yang menentukan bahwa bantuan pembiayaan perumahan swadaya diberikan kepada kelompok sasaran, sehingga perbuatan terdakwa merupakan perbuatan melawan hukum. Selanjutnya terdakwa mempergunakan sebagian uang hasil korupsi tersebut, yaitu sebesar Rp2.446.606.000,- untuk kepentingan pribadi, yaitu dibagikan kepada pengurus partai politik pendukung terdakwa dalam rangka Pemilihan Kepala Daerah Kabupaten Karanganyar tahun 2008, sehingga perbuatan terdakwa merupakan perbuatan merupakan korupsi politik. 
C. Filosofi Putusan Pemidanaan Melebihi Tuntutan dalam Perkara Korupsi Politik

Penjelasan Undang-Undang Tipikor menyatakan bahwa korupsi di Indonesia terjadi secara sistematik dan meluas sehingga tidak hanya merugikan keuangan negara, tetapi juga telah melanggar hak-hak sosial dan ekonomi masyarakat secara luas, maka pemberantasan korupsi perlu dilakukan dengan cara luar biasa. Makna cara luar biasa ini merupakan sebuah refleksi bahwa sangat sulit untuk menentukan arah awal dimulainya antisipasi pemberantasan tindak pidana korupsi di Indonesia (jika hanya dengan cara yang biasa/konvensional).

Kejahatan yang sudah terukur melalui kejahatan yang terstrukturisasi maupun kejahatan yang telah tersistematisasi sangat sulit untuk menentukan makna "pemberantasan" atau "eliminasi" terhadap perbuatannya, saat itulah dapat dikatakan korupsi sebagai suatu perbuatan yang beyond the law karena sangat sulit kadar pembuktiannya. Kesulitan pembuktian ini disebabkan oleh multi faktor antara lain kekuasaan, kuatnya para economic power di mana pengaruh kekuasaan ekonomi (konglomerat) dan bureaucratic power sebagai kekuasaan umum (pejabat birokrat) yang dapat dikatakan telah memosisikan mereka dalam status beyond the law, sehingga hukum sering dikatakan sebagai suatu retorika kekuatan politik saja (Adji, 2009: 95).

Korupsi dan (politik) kekuasaan, diibaratkan dua sisi dari satu mata uang. Korupsi selalu mengiringi perjalanan kekuasaan dan sebaliknya kekuasaan merupakan "pintu masuk" bagi tindak korupsi. Ada postulat yang mengatakan korupsi mengikuti watak kekuasaan. Jika kekuasaan berwatak sentralistis, korupsi pun mengikutinya berwatak sentralistis. Semakin tersentralisasi kekuasaan, semakin hebat pula korupsi di pusat kekuasaan itu. Jenis ini ditemukan di masa orde baru. Sebaliknya, jika yang terjadi adalah otonomi, seperti otonomi daerah, maka korupsi pun mengikutinya sejajar dengan otonomi tersebut. Karena kekuasaan berpindah dari satu pusat kekuasaan ke banyak pusat kekuasaan yang otonom, korupsi pun mengikutinya berpindah dari satu pusat kekuasaan kepada banyak pusat kekuasaan (Sanusi, 2009: 83). Penyalahgunaan (pen-kekuasaan/politik) ini tidak mampu diatasi oleh lembaga yang mewakili rakyat, korupsi menjadi sebuah perbuatan yang tidak dapat dihindarkan (Pramono, 2013: 109).

Perilaku korupsi politik merupakan tindakan merampas kehidupan rakyat, sehingga banyak rakyat kehilangan hak strategisnya untuk hidup layak dan mematikan harapan masa depannya. Korupsi politik merusak sumber daya ekonomi dan berdampak luas terhadap kualitas sumber daya manusia, dan munculnya berbagai macam kerentanan massal yang merendahkan derajat kemanusiaan. Korupsi politik merampas hak rakyat kebanyakan untuk mendapatkan pendidikan yang layak, dan menimbulkan kesenjangan ekonomi dan pendidikan (Alkostar, 2009: 177).

Hubungan penyalahguna, penjaja, makelar kekuatan politik dengan konglomerat yang tidak otentik (banyak konglomerat 'karbitan') itu berpilin berkelindan secara kolutif dan tanpa adanya kontrol hukumyang memadai. Disebabkan hubungan ilegal antara kekuatan politik yang liar dan kekuasaan ekonomi yang rakus, terjadilah di Indonesia krisis ekonomi serta ambruknya keuangan negara yang sangat parah dan dirasakan hingga saat ini. Pemegang kekuasaan politik biasanya "ketagihan" untuk tetap berkuasa dan tidak mau melepaskan kekuasaan yang telah dipegangnya. Untuk mempertahankan kekuasaannya penguasa biasanya memperkuat 
basis pendukung yang diukur dengan kadar loyalitas para kroni (Alkostar, 2008a: 2).

Pada perkara dengan terdakwa RISR ini dijelaskan konstruksi hubungan makelar politik dengan konglomerat serta penyalahguna kekuasaan politik, di mana diuraikan dalam pertimbangan majelis hakim tingkat kasasi bahwa "terdakwa RISR seharusnya mengetahui atau patut menduga bahwa uang yang diterima dari suaminya, yaitu saksi TIH melalui pegawainya NT (bendahara KSUS) merupakan dana yang diterima dari KSUS karena terdakwa mengetahui KSUS sebagai penyalur dana subsidi perumahan dari Kementerian Perumahan Rakyat, juga mengetahui saksi TIH (suami terdakwa) yang berkuasa penuh atas pengeluaran keuangan KSUS, sehingga perbuatan terdakwa menempatkan uang dari hasil korupsi merupakan tindak pidana pencucian uang sebagaimana diatur dalam Pasal 3 Undang-Undang Pencegahan dan Pemberantasan Tindak Pidana Pencucian Uang."

Ditinjau dari perspektif kriminologis, pencucian uang merupakan sisi lain dari korupsi yang tidak bisa dikesampingkan. Akibat korupsi inilah salah satu benefit atau advantage yang dihasilkan berupa aset atau harta kekayaan itu dimanfaatkan. Ketika aset atau harta kekayaan itu telah diperoleh, dapat dipastikan, entah cepat atau lambat, entah langsung atau tidak langsung, maka aset atau harta kekayaan itu akan dimanfaatkan (Kristiana, 2015: 7).

Dijelaskan pula oleh majelis hakim bahwa "terdakwa sebagai bupati bukan saja tidak menjadi pengayom, pelindung, panutan bagi rakyatnya, tetapi justru telah mengorbankan kepentingan rakyatnya untuk ambisi politik dan kepentingan pribadinya. Akibat perbuatan terdakwa, rakyat Kabupaten Karanganyar kehilangan peluang untuk memperoleh atau memperbaiki rumah sehingga niat baik pemerintah melalui program gerakan nasional pembangunan sejuta rumah menjadi terganggu, yang justru dilakukan oleh seorang pejabat penyelenggara negara/bupati."

Berdasarkan konstruksi ini maka dapat ditarik benang merah bahwa terdapat hubungan kausal antara tindak pidana korupsi dengan desain mempertahankan kekuasaan politik. Melalui kedudukan jabatannya yang status quo, didesain tindak pidana korupsi untuk menghasilkan pundi-pundi uang sebagai modal kontestasi politik. Bahkan secara ekonomi pula akan menguntungkan diri sendiri, orang lain atau korporasi yang berkaitan dengan usahanya memenangi kontestasi politik. Akibatnya rakyatlah yang sangat dirugikan, di satu sisi hak-hak kesejahteraannya telah dirampas dengan perilaku korupsi politik, dan di sisi lain hancurnya kepercayaan masyarakat terhadap sistem demokrasi yang "diperdayai" dengan cara-cara kotor.

Jika sudah diawali dengan kegiatan atau perilaku korupsi sebagai modal, maka sudah tentu akan menghasilkan sistem penyelenggaraan pemerintahan yang tidak kondusif dan hanya mementingkan kroni-kroni yang telah membantu pencapaian kedudukan/jabatan tersebut. Selanjutnya dikondisikan pula proses perencanaan, penganggaran hingga pengadaan barang/jasa yang lingkupnya tak hanya sebatas korupsi dalam tataran kebijakan eksekutif, tetapi juga terkait dengan penyalahgunaan kewenangan legislatif. Terhadap penanggulangan korupsi politik yang demikian maka diperlukan adanya aturan hukum (nomologos) dan prosedur hukum (teknologos) yang spesifik, karena menyangkut kejahatan yang berdimensi kekuasaan politik dan/ atau pihak yang mempunyai kekuatan ekonomi. 
Konsekuensi logis dari posisi politik dan ekonomi dari pelaku korupsi politik yang seperti itu, menuntut adanya pemberlakuan pembalikan beban pembuktian (shifting of bunden of proof) dan ketegasan maksimum pidana penegakan hukum yang terintegrasi (Alkostar, 2008b: viiviii).

Putusan pemidanaan melebihi tuntutan adalah salah satu langkah strategis untuk memberikan penjeraan kepada pelaku korupsi politik dan memberikan peringatan kepada "caloncalon" pelaku di masa yang akan datang agar tidak main-main dengan ketegasan penegak hukum. Merupakan kewenangan hakim memutus sesuai fakta persidangan dan keyakinannya memberikan pemidanaan melebihi tuntutan jaksa penuntut umum jika dirasa adil dan rasional. Hakim dapat memutus lebih tinggi dari tuntutan jaksa penuntut umum, namun tidak boleh melebihi batasan maksimum ancaman pidana yang ditentukan (Sudharmawatiningsih \& Suhariyanto, 2015: 67) oleh Undang-Undang Tipikor.

Mengenai masalah berat ringannya atau lamanya pidana ini merupakan wewenang judex facti yang tidak tunduk pada kasasi, kecuali apabila judex facti menjatuhkan pidana melampaui batas maksimum yang ditentukan undang-undang sebagaimana ditentukan dalam Putusan Mahkamah Agung Republik Indonesia Nomor 1953K/Pid/1988 tanggal 23 Januari 1993 (Mulyadi, 2010: 14).

Secara normatif tidak ada ketentuan undangundang khususnya KUHAP yang mengharuskan hakim menyesuaikan putusan pemidanaannya dengan tuntutan jaksa penuntut umum. Hakim bisa dan dimungkinkan untuk menerobas atau melebihi tuntutan maksimum yang diajukan oleh jaksa penuntut umum selama masih dalam koridor batas maksimum ancaman pidana pasal yang didakwakan (Sudharmawatiningsih \& Suhariyanto, 2015: 62).

Hakim memiliki kebebasan dalam melaksanakan tugasnya di mana tidak saja menegakkan hukum, melainkan juga sebagai penegak keadilan. Pertimbangan hukum yang cukup terkait adanya hal yang memberatkan dengan didasari sebuah keyakinan yang mantap akan sebuah keadilan substantif dapat menjadi landasan konstitusional bagi hakim menjatuhkan putusan pemidanaan lebih tinggi dari tuntutan jaksa penuntut umum. Hakim memiliki kebebasan untuk memidana melebihi tuntutan untuk memenuhi rasa keadilan dan nurani atau keyakinan yang dimilikinya terhadap tujuan pemidanaan yang terbaik bagi kepentingan pelaku, korban, kepentingan masyarakat/ umum maupun bagi eksistensi negara hukum (Sudharmawatiningsih \& Suhariyanto, 2015: 68).

Umumnya hakim pengadilan tipikor memberikan pemberatan sesuai dengan konstruksi normatif dan tidak memperluas penafsiran hingga membuat suatu klasifikasi baru terkait perbuatan korupsi di luar yang sudah ditentukan jenisnya dalam peraturan perundangundangan, misalnya dengan menegaskan hal baru sebagaimana korupsi politik ini. Bagi hakim yang positivistik tinggal menemukan penafsirannya karena undang-undangnya sudah tersedia dan siap saji sebagai premis mayor terhadap premis minornya, lalu menarik kesimpulan.

Hukum positif sebagai premis mayor, dan fakta hukum sebagai premis minor. Idealnya, putusan yang mendekati keadilan tentu bukan putusan yang penalaran hukumnya hanya menempatkan hakim sebagai mulut atau corong undang-undang. Kita dapat menilai putusan 
yang berkualitas yang argumentasinya dapat memulihkan kepercayaan masyarakat. Hakimnya tidak hanya membaca teks, tetapi berusaha menembus apa yang ada di balik teks, berdialog dengan konteks seraya melibatkan kepekaan nuraninya (Mappise, 2015: 36-37).

Sangat dipahami secara mendalam oleh majelis hakim dalam putusan kasasi ini bahwa praktik korupsi yang terjadi secara meluas dan sistematis dapat membawa bencana bagi kehidupan masyarakat dan juga merupakan pelanggaran terhadap hak-hak sosial dan hakhak ekonomi masyarakat (Waluyo, 2016: 20). Mengingat undang-undang telah menjelaskan bahwa tindak pidana korupsi tidak lagi digolongkan sebagai kejahatan biasa (ordinary crime) tetapi telah menggolongkannya menjadi kejahatan luar biasa (extra ordinary crime).

Berkaitan dengan hal ini, Rahardjo mengelaborasi bahwa oleh bangsa Indonesia, korupsi yang meluas dinamakan extra ordinary crime. Kita tidak berhenti pada pemberian nama yang menyeramkan itu, tetapi juga mengandung makna memberantas dengan cara yang sesuai dengan keparahan korupsi (Alkostar, 2009: 170). Arief juga mengingatkan bahwa untuk menanggulangi penyalahgunaan kekuasaan itu, sewajarnya ketentuan hukum pidana yang ada diefektifkan dan disempurnakan. Namun patut dicatat bahwa upaya penanggulangan dengan hukum pidana mempunyai keterbatasan (Arief, 2008: 179).

Dionysios Spinellis menyatakan bahwa terdapat fenomena kembar yang menjadi karakteristik dari kejahatan ini, yaitu penalization of politics dan the politicizing of the criminal proceedings. Dijelaskan olehnya bahwa karena tindak pidana ini berhubungan dengan politicians in office, maka tidak dapat dihindari lawan-lawan politik sering mencoba menggunakan kesempatan untuk keuntungan politik. Demikian juga media massa mempublikasikan skandal politik untuk berbagai alasan. Skandal-skandal politik ini terkadang meratakan jalan bagi penuntutan pidana untuk tujuan politik semata-mata.

Berdasarkan alasan-alasan itulah muncul fenomena bahaya penalization of politics. Ketika proses pidana terhadap politikus dibuka/digelar maka mungkin terdapat pendukung dan seluruh partai mencoba memengaruhi proses pidana itu sehingga tidak dapat dihindari terjadinya the politicizing of the criminal proceedings. Kedua fenomena kembar ini menambah kesulitan dalam melakukan pendeteksian, penuntutan, dan pemidanaan terhadap kejahatan ini (Arief, 2008: 179).

Merujuk dengan pendapat Rahardjo tersebut di atas, maka inisiasi membentuk kualifikasi "khusus" korupsi politik oleh majelis hakim ini dapat digolongkan sebagai usaha memaknai pemberantasan korupsi dengan cara yang "sesuai dengan tingkat keparahan korupsi." Terlebih di era demokratisasi yang menjunjung kebebasan berpendapat dan berkompetisi dalam mencapai kedudukan politis di pemerintahan, tercederai dengan celah perilaku busuk oknum "elit politik" yang dengan ambisius melakukan perbuatan melawan hukum berupa korupsi untuk kepentingan kekuasaannya. Kemerosotan moral masyarakat terhadap kepercayaan terselenggaranya pemerintahan yang good governance merupakan imbas dari perilaku korupsi politik. Jadi betapa masifnya kerusakan dari tindak pidana korupsi politik jika dibandingkan dengan tindak pidana korupsi yang sifatnya umum (tanpa menggunakan sarana politik). 
Mengingat bahwa motif dari tindak pidana korupsi dari keduanya (korupsi yang umum dengan korupsi politik) adalah sangat berbeda. Pada jenis korupsi yang sifatnya umum, motivasinya cenderung corruption by need yaitu lebih menekankan pada adanya kebutuhan hidup yang harus ditanggung oleh seseorang. Kebutuhan hidup ini bisa kebutuhan dirinya sendiri, kebutuhan hidup istri dan anaknya maupun kebutuhan hidup sanak keluarganya. Ada pula yang melakukan korupsi karena "terpaksa" karena himpitan ekonomi menjadi salah satu alasan utamanya.

Berbeda dengan korupsi politik yang didasarkan atas corruption by greed, motif pelaku melakukan tindak pidana korupsi sematamata karena motif ekonomi atau karena rakus (Pramono, 2013: 110) akan kekuasaan/kedudukan politik. Efek krusial dari tindak pidana korupsi politik ini sangat luas dan tidak sebanding dengan jenis korupsi dengan motivasi corruption by need. Sangat tepat jika diberikan putusan pemidanaan yang lebih berat dan menjerakan secara maksimal. Sebagaimana suatu adagium bahwa kejahatan akan mengikuti perkembangan masyarakat sehingga semakin maju dan canggih sistemnya maka cara dan modus operandinya akan juga semakin canggih. Model perkembangan kejahatan yang berubah ini harus diantisipasi dengan model penegakan hukum yang secara inovatif berkembang dan progresif sebagaimana Putusan Nomor 1885K/PID.SUS/2015.

Selayaknya pemberantasan korupsi harus menempati posisi strategis sebagai upaya yang secara konseptual menempatkan institusi politik harus bekerja untuk menciptakan keseimbangan yang mungkin muncul antara pertentangan kepentingan perorangan, sebagaimana juga pertentangan kepentingan antara berbagai unsur dan komunitas dalam masyarakat (Pramono, 2013: 110).

Formula dari Klitgaard sangat relevan dihubungkan yaitu Corruption = Monopoly + Discretion - Accountability. Seseorang cenderung untuk menemukan korupsi ketika sebuah organisasi atau seseorang memiliki monopoli atas barang atau jasa, memiliki keleluasaan (diskresi) untuk memutuskan siapa yang akan menerima dan berapa banyak orang yang akan mendapatkan barang atau jasa, serta tidak akuntabel (Kurniawan, 2017: 11). Untuk menciptakan akuntabilitas tersebut maka sikap kritis masyarakat atas berbagai usaha monopoli kekuasaan yang mengarah pada korupsi politik harus dilakukan pencegahan. Diperlukan kontrol sosial dari masyarakat dalam negara demokrasi, seperti yang diperankan oleh lembaga swadaya masyarakat, organisasi sosial, perguruan tinggi dan media massa menjadi faktor determinan dalam penanggulangan korupsi politik (Alkostar, 2008a: 13).

\section{KESIMPULAN}

1. Secara normatif, Undang-Undang Tipikor tidak mengatur tindak pidana korupsi politik. Akan tetapi dalam realitas penegakan hukum pemberantasan tindak pidana korupsi khususnya dalam praktik peradilan (putusan pengadilan), istilah korupsi politik mengemuka sebagai sebuah bentuk pemberatan atas setiap formulasi tindak pidana korupsi yang formal diatur dalam undang-undang.

2. Identifikasikorupsipolitik disebutkan dalam Putusan Nomor 1885K/PID.SUS/2015 atas nama terdakwa RISR dan Putusan Nomor 1261K/Pid.Sus/2015 atas nama terdakwa 
AU. Perbedaan dari kedua putusan tersebut ada pada penerapan pasal yang digunakan oleh majelis hakim, terhadap AU dikenakan Pasal 12 huruf a Undang-Undang Tipikor, dan terhadap RISR dikenakan Pasal 2 ayat (1) Undang-Undang Tipikor. Selain itu adanya perbedaan dalam hal putusan pemidanaannya yaitu pada perkara RISR penjatuhan pidana penjaranya melebihi tuntutan dari jaksa penuntut umum.

3. Umumnya hakim pengadilan tipikor memberikan pemberatan sesuai dengan konstruksi normatif dan tidak memperluas penafsiran hingga membuat suatu klasifikasi baru. Inisiasi membentuk kualifikasi "baru" korupsi politik oleh kedua putusan Mahkamah Agung tersebut dapat digolongkan sebagai usaha memaknai pemberantasan korupsi dengan cara yang "sesuai dengan tingkat keparahan korupsi." Putusan pemidanaan melebihi tuntutan merupakan cara memberikan penjeraan kepada pelaku korupsi politik dan bisa dijadikan peringatan kepada "calon-calon" pelaku di masa yang akan datang agar tidak main-main dengan ketegasan penegak hukum.

\section{DAFTAR ACUAN}

Adji, I.S. (2009). Korupsi \& penegakan hukum. Jakarta: Diadit Media.

Alkostar, A. (2008a, Januari). Mengkritisi fenomena korupsi di parlemen. Jurnal Hukum, 15(1), 1-13. (2008b). Korupsi politik di negara modern. Yogyakarta: UII Press.
(2009, Oktober). Korelasi korupsi politik dengan hukum \& pemerintahan di negara modern (Telaah tentang praktik korupsi politik \& penanggulangannya). Jurnal Hukum, 16, 155179.

Arief, B.N. (2008). Masalah penegakan hukum \& kebijakan hukum pidana dalam penanggulangan kejahatan. Jakarta: Kencana.

Beritasatu. (2017). TII: korupsi di Indonesia didominasi korupsi politik. Diakses dari http:// www.beritasatu.com.

Dirgantara, M.A., et al. (2017, Januari). Analisis yuridis kebijakan pemidanaan dengan hukuman kebiri terhadap pelaku pedofilia. USU Law Journal, (5) 1, 119-127.

Failin. (2017, September). Sistem pidana \& pemidanaan di dalam pembaharuan hukum pidana Indonesia. Jurnal Cendekia Hukum, (3)1, 14-31.

Ganarsih, Y. (2016). Penegakan hukum anti pencucian uang \& permasalahannya di Indonesia. Jakarta: Rajagrafindo Persada.

Iskandar, N., etal.(2013).Penyalahgunaankewenangan (abuse of power) dikaitkan dengan tindak pidana korupsi dalam pelaksanaan birokrasi. Jakarta: Pusat penelitian dan Pengembangan Kejaksaan Agung.

Kompas. (2017, Desember 28). Korupsi politik masih menjadi tren. Diakses dari www.pressreader. com.

Kriekhoff, V.J.L. (2015). Metode penelitian hukum (bagian I). Jakarta: Program Pascasarjana Fakultas Hukum Universitas Indonesia.

Kristian \& Gunawan, Y. (2015). Tindak pidana korupsi: Kajian terhadap harmonisasi antara hukum nasional dan the united nations convention against corruption (UNCAC). Bandung: Refika Aditama. 
Kristiana, Y. (2015). Pemberantasan tindak pidana pencucian uang: Perspektif hukum progresif. Yogyakarta: Thafa Media.

Kurniawan, T. (2017). Isu diskresi dalam kasus korupsi kepala daerah yang ditangani oleh Komisi Pemberantasan Korupsi pada periode 2004-2010 \& telah memiliki kekuatan hukum tetap. Disertasi. Depok: Fakultas Ilmu Sosial dan Ilmu Politik Program Doktor Ilmu Administrasi Universitas Indonesia.

Lisi, I.Z. (2017). Hukum acara pidana: Teori \& implementasi. Samarinda: Fakultas Hukum Universitas Mulawarman.

Mappise, S. (2015). Logika hukum pertimbangan putusan hakim. Jakarta: Kencana.

Marzuki, P.M. (2014). Penelitian hukum. Jakarta: Kencana.

Mulyadi, L. (2010). Seraut wajah putusan hakim dalam hukum acara pidana Indonesia. Bandung: Citra Adtya Bhakti.

Patiro, Y.M. (2013). Antara perintah jabatan \& kejahatan jabatan pegawai negeri sipil. Bandung: Keni Media.

Pelafu, F.L. (2017, Mei). Pelaksanaan putusan pengadilan dalam perkara pidana berdasarkan kitab undang-undang hukum acara pidana. Jurnal Lex Crimen, VI(3), 86-93.

Pramono, A. (2013, Januari). Kekuasaan \& hukum dalam perkuatan pemberantasan korupsi. Jurnal MMH, 42(1), 105-113.

Sani, A., et al. (2015, Agustus). Pemidanaan anak menurut konsepsi hukum Islam \& hukum pidana Indonesia. Jurnal Ilmu Hukum, 3(3), 11-20.

Santoso, Y.B., \& Ma'ruf, U. (2017, Juni). Kebijakan pembuktian \& penuntutan oleh jaksa penuntut umum dalam pemberantasan tindak pidana korupsi. Jurnal Hukum Khaira Ummah, 12(2), 359-366.

Sanusi, A. (2009, Juli). Relasi antara korupsi \& kekuasaan. Jurnal Konstitusi, 6(2), 83-104.

Sudharmawatiningsih \& Suhariyanto, B. (2015). Pengkajian tentang putusan pemidanaan lebih tinggi dari tuntutan jaksa penuntut umum. Laporan Penelitian. Jakarta: Pusat Penelitian dan Pengembangan Hukum dan Peradilan Mahkamah Agung.

Suhariyanto, B. (2015, Desember). Eksistensi pembentukan hukum oleh hakim dalam dinamika politik legislasi di Indonesia. Jurnal Rechtsvinding, 4(3), 413-429.

Suhendar. (2015). Konsep kerugian keuangan negara (Pendekatan hukum pidana, hukum administrasi negara \& hukum pidana khusus korupsi). Malang: Setara Press.

Waluyo, B. (2016). Pemberantasan tindak pidana korupsi (Strategi \& optimalisasi). Jakarta: Sinar Grafika. 